\title{
Simulacral, genealogical, auratic and representational failure: Bushman authenticity as methodological collapse
}

\author{
William F. Ellis
}

\begin{abstract}
This article engages with the concept of authenticity as deployed in anthropology. The first section critiques authenticity as a simple reference to cultural purity, a traditional isomorphism or historical verisimilitude or as an 'ethnographic authenticity'. Demarcation of authenticity must take into account philosophical literature that argues that authenticity is an existential question of the 'modern' era. Thus, authenticity is offered to us as individuals as a remedy for the maladies of modernity: alienation, anomie and alterity. Authenticity is then discussed as a question of value within an economy of cultural politics that often draws on simulacra, creating cultural relics of dubious origin. The final section discusses various methodological failures and problematiques that are highlighted by the concern for, and scrutiny of, authenticity. The first is the simulacral failure. The subjects of anthropology are mostly real flesh-and-blood people-on-theground with real needs. In contrast is the simulacral subject, the brand, the tourist image, the media image or the ever-familiar hyper-real bushmen. Lastly, the article considers what Spivak calls 'withholding' - a resistance to authentic representation by the Other. Resistance suggests a need for a radically altered engagement with the Other that includes both a deepening, and an awareness, of anthropology as a process of common ontological unfolding.
\end{abstract}

\section{Prelude}

What are the ends of authenticity? Where does a discourse of authenticity lead? As Walter Benjamin (1969) and Theodor Adorno (1964) watched the world plunge into William Ellis World War II, they viewed the very 'modern' angst that is authenticity as pathology of power and capital. Benjamin (in Jay 2006) saw in talk of authenticity the growth of fascism (as a political arm of capital) and eventually war. Adorno (1964, 1987, 2003) saw the extermination of the inauthentic and migrants by those who perceived themselves and their kin as autochthonous. Authenticity suggests: 'All arrivals are to be excluded and if they do not move they will be made to do so.' Think Nazi Germany, apartheid, Israel/Palestine, Rwanda, Bosnia and Serbia, Mbotu's Zaire, Idi Amin's Uganda, India and Pakistan after independence, and now Zimbabwe.

This prelude reveals my awareness of authenticity as an ideological device, one that has been used in the past and continues to be used as a means of exclusion, especially in the service of ethno-nationalistic agendas. Heidegger (1927) focuses on authenticity as being an individualistic attribute to a conception based in groups (Jay 2006). Authenticity presented as an attribute of a group is at its most dangerous, because it is at precisely this 
moment that authenticity expresses its antagonism to the inauthentic most violently. The use of authenticity is a double-edged sword that can do as much harm to the authenticated as to the authenticator (Feuser 1988).

\section{Introduction}

Contemporary anthropologists seemingly cannot find the authentic 'Other' anywhere! When first encountering the authentic I doubted this claimed and performed status. The concomitant searches for cultural purity, existential veridicality, the commodity price of cultural life as well the search for methodologies that locate, verify and author(ise) these authenticities, all fall short. Some are at pains to find the methods, theories, new insights, nuances and even to engage in perspectival experiments to help us describe the 'Other' more authentically. These searches and devices are clearly a 'nostalgia for lost origins' (Derrida 1972). This nostalgia has also characterised anthropology as an epistemic endeavour. Having taken many forms, anthropology has not been resolved nor completely abandoned - it has simply transformed from one form to another, especially within the Western episteme.

Anthropology and Western philosophy cannot and have not been able to locate the prelapsarian, the true authentic human, the person at the moment after animal thought ceases. Both disciplines have searched for the ethnological representative of Adam and Eve. The prelapsarian 'Other', the authentic and the right methods to represent them, elude us all the time and, if we do not find the authentic, then anthropology seems pointless. This search for the essence of humanity, the true form -in short, its authenticity -has been most avidly sought among 'Stone Age peoples'-those apparently perfect models of early human life. However, most contemporary anthropologists agree that what were once considered to be paragons of authentic humanity, foragers and other non-Western societies, cannot deliver the West from its alienated and de-natured problematic selves. Anthropology has had a unique engagement with the search for the authentic that needs to be unpacked-the gist of my objective here.

World War II, they viewed the very 'modern' angst that is authenticity as pathology of power and capital. Benjamin (in Jay 2006) saw in talk of authenticity the growth of fascism (as a political arm of capital) and eventually war. Adorno (1964, 1987, 2003) saw the extermination of the inauthentic and migrants by those who perceived themselves and their kin as autochthonous. Authenticity suggests: 'All arrivals are to be excluded and if they do not move they will be made to do so.' Think Nazi Germany, apartheid, Israel/Palestine, Rwanda, Bosnia and Serbia, Mbotu's Zaire, Idi Amin's Uganda, India and Pakistan after independence, and now Zimbabwe.

This prelude reveals my awareness of authenticity as an ideological device, one that has been used in the past and continues to be used as a means of exclusion, especially in the service of ethno-nationalistic agendas. Heidegger (1927) focuses on authenticity as being an individualistic attribute to a conception based in groups (Jay 2006). Authenticity presented as an attribute of a group is at its most dangerous, because it is at precisely this moment that authenticity expresses its antagonism to the inauthentic most violently. The use of authenticity is a double-edged sword that can do as much harm to the authenticated as to the authenticator (Feuser 1988). 
The first section moves beyond the use of authenticity as a simple reference to cultural purity, a kind of traditional isomorphism or historical verisimilitude (Bruner 1994, 2001; Handler and Saxton 1988) or as an 'ethnographic authenticity' (Carrier 2009). This refusal to simply use authenticity as a cultural purity may seem a familiar criticism of essentialism and the idea of bounded 'cultures'. As a critique of authenticity, however, it is not sufficient to focus on authenticity as a 'cultural' attribute or process. Reframing outmoded concepts such as tribe or recuperating ethnic monikers as being about authenticity or authentication do not wholly capture the nuances of authenticity. Attempts to examine and demarcate authenticity must take into account a body of philosophical literature that argues that authenticity is an existential question of the 'modern' era. In other words, authenticity is about an individual's aspirations to live the best possible life despite the limitations and contingencies of the human condition. Authenticity is thus offered as a remedy for the maladies of modernity. Claims are made that with authenticity we can overcome alienation by claiming back the fruits of our labour; we rid ourselves of anomie by finding our identity and belonging; we transcend alterity by embracing it and staking equal claim to the world and its resources. This take has been duly called the 'search for authenticity', because adherents are engaged in attempts to recover lost presence. These are false hopes; 'recovery' is not possible because those who cling to this type of authenticity risk being 'paralyzed by the melancholy of their nostalgia for a lost past' (Ghosh 1998).

Those who 'buy' into authenticity view it as part of an economy of cultural politics in which signs, as measures of value, circulate for the production of commodities. Authenticity in this economy often draws on simulacra and creates cultural relics of dubious origin.

The final section discusses various methodological failures and problematiques. The first is simulacral failure. As regards authenticity and simulacra, a distinction needs to be made between two phenomena. The subjects of anthropology are, for the most part, real people-on-the-ground with real needs. In contrast is the simulacral subject (the lower case $b$ for bushman (after Rasool and Hayes 1998), the brand, the tourist image, the media image or the ever-familiar hyper-real bushmen. In South American contexts, the creation of a hyper-real Indian (in the South African case a hyper-real bushman) conveniently served the need for bureaucratic efficiency of various Indian organisations and non-governmental organisations (NGOs) (Ramos 1992). This representation is easily made into an image that can be conveniently marketed. The simulacral subject, that is bushman, is created to serve the need for bureaucratic efficiency and is good for court cases, films, books, marketing, land claims, NGO reports, policy and the like, but does not always deliver for those caricatured, parodied or simplified as simulacra.

The breakdown of the genealogical method in the examination of the 'Other' is now examined. When it concerns the 'Other', genealogy, as a method, can only make reference to what Benjamin (1969) terms an aura of authenticity. This aura is that semblance of the original state that copies retain; hence anthropology can only recover fragments of the original. As an engagement with Western thought, genealogy seems sufficient; however as an attempt at revelation of the 'Other' it is often simply an auratic critique, a standpoint

\section{https://repository.uwc.ac.za/}


that refers to an insufficiently mourned past (Mufti 2000). An auratic reading laments the loss of a loosely described past bathed in a glow of romanticism and, although the original object is gone, the aura remains. Lastly, I consider what Gayatri Spivak (1990: 16) calls 'withholding'-a resistance to authentic representation by the 'Other'. This resistance to representation suggests the need for a radically altered engagement with the 'Other'.

\section{The problem of Bushman authenticity in South Africa ${ }^{1}$}

Many terms are used here (San, Bushmen, southern Kalahari San, łKhomani San, Boesman and bushman) to indicate the people who were the participants or subjects in the study. 'San' is used to denote those former foragers claiming 'first nation' status; it is preferred as an umbrella category although it is actually a derogatory term employed by Nama speakers (see Biesele and Hitchcock 2010, Wilmsen 1989). 'Bushman', and the Afrikaans Boesman, are used either as a self-referent or when employed by sources, texts or authors to describe the group under study. While this may be the convention employed here, the terms San and Bushman are so intricately interwoven that they are impossible to separate (Douglas 1995; Voss 1990). When bushman is used it denotes a representational category, a simulacrum not an actual 'people'. The regional-geographical referent, southern Kalahari San, is used when indicating the ethno-linguistic community of that region of South Africa, and also when speaking about this specific group historically. The predominant term $\neq$ Khomani San, rather than meaning an ethnic unit, refers to a specific collective that was formed during the land claims process (Crawhall n.d.; Ellis 2010).

\section{Absence and presence in the landscape}

On his journey to find the San, Rupert Isaacson $(2000,2001)$ was told that none exist in South Africa. Popular and academic perceptions were that the last 'pure' remnants, who roamed much of the subcontinent prior to the arrival of the Bantu-speaking groups (circa 40oAD) and the European colonists (17th century), were only to be found in Botswana and Namibia (see, e.g., Humphreys 1985; Marshall 1976; Tobias 1956). Besides South Africa, San descendants continued to live in parts of Malawi, Angola, Zimbabwe, Zambia, and until the last one was murdered in 1988, in Swaziland (Suzman 2001).

It is only with extensive academic work and paradigmatic review that the continued San presence outside Namibia and Botswana became 'known'. This review is not a matter of challenging the previous revisions by means of the 'Kalahari Debates' (see Barnard 1990; Solway and Lee 1990; Wilmsen and Denbow 1990), or those that had earlier proposed a placement of the Khoi-San on a spectrum where they could oscillate from hunter to herder or vice versa (Bredenkamp 1991; Smith 1990), but is also a matter of political and communal reorientations.

With the exception of Botswana, new legal frameworks for access to land and natural resources have recently emerged, which allowed for a quest to revive Khoi-San culture based on privileged access to land and ecology (see Ellis 2010). This entitlement is not solely linked to the land but also to the emergence of cultural systems through this resource, for example, the hunting and gathering cultural formation as a function of land claims and ecology. That is, in the present bushman, identity emerges or re-emerges because of the renewed access to land and natural resources. 
Khoi-San descendants have in the political present begun to think it possible that they might revive and reclaim Khoi-San identity despite the obvious lack of perceptible markers of ethnographic authenticity, such as language, 'cultural practices', dress and the like. It is within these shifts in regional policy on land and natural resources that the regional revival of Khoi-San identity occurs.

This begs the question: Where do the San people who lodged a land claim in the South African Parliament and the other two groups living inside its boundaries come from; how and why did they 'reappear'? Officially, three decades ago, no San lived in South Africa, yet by the mid-1990s three distinct groups had re-emerged onto the political landscape. The first are the so-called 'Bushmen Battalions'-the !Xu or Khwe, late of Schmidtsdrift in the Northern Cape. Second is the łKhomani, a group reconstituted as a result of the initiation of a land claim lodged in the mid-1990s. Last is the so called 'Secret San', a group of individuals who were unwilling to 'reveal' their status and openly identify themselves as San. They include groups of scattered individuals living in areas of South Africa that are traditionally considered to be occupied by Nguni-speaking farmers (Prins 2009).

The 'Bushmen Battalions' initially lived at Schmidtsdrift in the Northern Cape, but moved as part of the land redistribution programme (Robins 2001). Linguistically distinct, the !Xu are from Namibia and the Khwe from southern Angola. Both groups served with the South African Defence Force (SADF) in conflicts with the South West African People's Organisation (SWAPO) and against the Movimento Popular de Libertação de Angola ${ }^{2}$ (MPLA). The SADF recruited and trained them. It was perceived that they had a natural hatred for 'blacks' who hunted them on both sides of the border; and that their exceptional skills in tracking and veld-craft made them good soldiers (Erasmus 1997).

The end of the war in 1989 saw the SADF withdraw from the region. The San feared retribution 3 from their fellow Namibians and Angolans, and were transferred to a resettlement camp near Kimberley and granted South African citizenship (Sharp and Douglas 1996). After a rocky start characterised by internal conflicts, uncertainty about continued employment in the army, contesting land claims and a myriad social problems, the groups entered into discussions with the now South African National Defence Force (SANDF) and the Department of Land Affairs (DLA) that made the future seem a bit more certain (Douglas n.d.). The two groups later moved onto land received through the redistribution programme, at Platfontein (see Robbins 2006). This, in brief, is how the !Xu and the Khwe re-emerged on the South African landscape. More accurately, the story of the !Xu and the Khwe is one that should be characterised as a series of relocations, not necessarily a re-emergence. The two distinct groups were relocated in 2004, yet they continue to experience various problems characterised as issues of coherence, largely the result of 'forced togetherness of the past' (Den Hertog 2013: 356).4

The re-emergence of the $\neq$ Khomani appears more complex as they are from South Africa and were not brought from 'elsewhere'. In order to understand their re-emergence, I will briefly examine the conditions that led to their disappearance. In the 1930s, the so-called 'Wits expedition' led by Raymond Dart sought to seek out the 'purest' San people. They went, on the advice of Dorothea Bleek, into the southern Kalahari to 'the furthest end of

\section{https://repository.uwc.ac.za/}


the Union' (Maingard 1937). Once the fieldwork had been completed some members of the expedition tried to establish a reserve for the San people of the southern Kalahari, but the response of the government and local farmers was negative. A government report labelled the San of this region as 'fakes' (Gordon 1999). In this particular instance, the argument put forward was that the San group in question was completely 'bastardized', that they had 'lost their culture', that many spoke Afrikaans and were employed on the farms of Europeans as domestic workers or farmhands (Gordon 1995: 282). Government and farmers claimed that these people were no longer Bushmen and therefore not entitled to have land set aside for their sole use, for example, as a native reserve for the preservation 5 of their 'traditional' lifestyle (Boydell 1948). This was the first important instance where the 'authenticity' construct/debate concerning specifically the southern Kalahari San, arose. Several decades passed and the descendants of this group continued to live in the Mier and wider Gordonia region. Some were still considered to be 'Bushmen' by the local farmers and the authorities within the Kalahari Gemsbok National Park.

The final death knell for the San of South Africa came when, in terms of the Population Registration Act, 30 of 1950, most of the San were registered, and thus reinscribed onto the South African political landscape and legislation, as coloured (Steyn 1984). With the implementation of the act, the San officially ceased to exist.

One of the reasons was that the former category, 'Bushmen', was seen to represent the very lowest point in the hierarchy of 'races'. In this regard the San were originally classified as a 'native race'6 (Carstens 1966). Their reclassification as coloureds was perceived to be a 'step up' in the racial hierarchy of South Africa at the time. For example, one participant, the late Ouma |unnas, proudly told me how they lived and worked as coloureds in the Kalahari Gemsbok National Park and on farms in the region, and how they were prevented from interacting with Dawid Kruiper and other 'Bushmen'. It was only after 1994, when the political landscape in South Africa changed, and with a new constitution in the making, that many San again began to refer to themselves as San or 'Bushmen'. Boonzaier and Sharp (1993), who found similar processes at work in the revival of Nama identity, argued that under apartheid it was better to be known as coloured than as Nama. This was similarly the case for the 'Bushmen' (see also Robins 1997, 2000, 2001).

The process of re-emergence is a fundamental part of government strategies to manage these groups, and authenticity is the main tool used to validate or dispute claims. Thus, both in the present and in the past there have been active processes of authentication and de-authentication, contingent on the particular political aims of those in power. The process of authentication was apparent in the 1930s, with attempts to establish a San homeland in the Kalahari.7 Such managed re-emergence and authentication resurface again in racial reclassification during the formative years of apartheid, and once more in the present with regard to the $¥$ Khomani land claim and that of the Schmidtsdrift Bushmen. In the postapartheid period authenticity has become vital in the construction of citizenship, claims to citizenship and the subsequent resource distribution that may result. It is as if successive regimes have had to allow for a rediscovery and re-emergence of the San, and to re-script the story of these representations into their foundation myths. At each point of shift in the political landscape, bushman, Bushman, San and whatever 
other name used, needed to be reinvented to establish the notion of a nation. The San must be let into and included in the nationalist narratives, because one cannot tell the story of southern Africa without them.

Two key developments set the stage for San identity and people to re-emerge in South Africa post-1994. The first was the new political dispensation; the second, land reform legislation. Steven Robins (2000) comments that political changes facilitated the reclaiming of these identities without the stigmas associated with them during apartheid. Land reform legislation, and especially the Restitution of Land Rights Act, 1994, enabled the $\neq$ Khomani to lodge the claim. The process played a key role in the reconstitution and construction of the group known as the $\neq$ Khomani San. Within this context it is apparent that the San never really 'disappeared', but rather had been renamed and stripped of representation and representativeness by policies and perceptions of the past.

Once these policies and perspectives had been removed, those who considered themselves San $^{8}$ reasserted their position and identity. It is within this context that groups like the 'secret' San reappeared, albeit warily (see Prins 2009). In other words, it is in the 'new South Africa' that many new identities could be asserted, exercised and claimed (see Comaroff and Comaroff 1999, 2009).

The perception that the San had 'vanished', were bastardised through miscegenation or were at least 'culturally extinct' in South Africa would come back to haunt the $¥$ Khomani after they had lodged their land claim. Many who encountered the $¥$ Khomani - from tourists, farmers, and former neighbours to researchers and the media - expressed surprise that the San still existed. Others, like the government and farmers in the 1930s, were sceptical about the 'authenticity' of people claiming to be San. In fact, Mier residents who claimed either coloured or Baster ${ }^{9}$ identity, reacted with astonishment and questioned how their neighbours, friends and colleagues, whom they had known as coloureds or Basters, were suddenly calling themselves San.

The following sections consider the question of $¥$ Khomani authenticity. The etymology deals with some issues of translation and I attempt to operationalise the term 'authenticity'.

\section{A note on etymology, definition, translation and operationalisation}

Let us consider authenticity as mere word, first in terms of etymology. Second, a brief 'definition in the negative' is offered. Lastly, it is necessary to offer a brief note on translations of the concept of authenticity from cited texts.

\section{Etymology}

'Authenticity' has two Greek roots: auto = self and hentes $=$ made, hence authenticity is about being self-made. This particular definition reveals the flaws in the concept, particularly as it relates to authenticity as cultural purity. The entity in question, say a painting, ${ }^{10}$ is an object that is authored by its own hand, has its own authority and is given a primal, chthonic origin, if not a simple and pure divine derivation. An entity that drafts its own destiny is just too convenient for primordialist, essentialist, racist and ethnic exclusionary agendas.

\section{https://repository.uwc.ac.za/}


Most dictionaries point to three aspects of the word: particularity, lack of artifice and some kind of conformity to a pre-existing form or item. Authenticity as particularity suggests that an object is unique, singular, primal and, in a sense, never before seen. In the second sense (lack of artifice) a phenomenon is not some echo or reproduction of a pre-existing form. If not made by god(s), and if human hands had a role in its production, then it is assumed to be divinely inspired (here the links to autochthony are suggested). Lastly, if reproduction is uncontestable then authenticity means that the phenomenon in question has to conform to, or at least illustrate, a verisimilitude or isomorphism with that of which it is a reproduction or copy.

The real is something radically different from the authentic. Jean Lyotard (1991) asks: Can thought continue without the body? He asks the reader to consider the solar holocaust (coming in a few billion years), and whether any human thought or reflection on the universe can outlast this cataclysm. With this apocalypse what we know and think about the world will disappear, yet some 'things' will escape and survive this event. Those that remain are the 'real', they continue to exist regardless of our ability to conceptualise and theorise about them. In this view the authentic is a product of the human brain and only therein lies its genesis. All that is 'real' lies within the realm of the pre-discursive and the pre-social. The discussion below relies on this simple point of departure, namely that the authentic is a socio-cultural product.

\section{Translation}

Let us begin with the response by Adorno to Heidegger (my point is limited to single terms and not the general debate) and German existentialism in general through the text entitled 'The jargon of authenticity'. I am fairly confident that in the English translations the terms are congruent and that they exhibit a degree of fidelity to the original.

In the case the San of the southern Kalahari, another set of translation issues arises. Most of the informants use Afrikaans as mother tongue, and the words I include as referring to or indicating authenticity are as follows: Regte $=$ real, egte $=$ genuine, ware $=$ true, werklik $=$ real, opregte $=$ upright, real, true. While the terms outentiek or outentiteit (authenticity) exist in Afrikaans, they are Anglicisms that were not frequently (if ever) employed by anyone in the field. These terms are often used in Afrikaans as alliterations or rhyming idioms, e.g., regte egte $=$ really genuine or werklik waar $=$ really true. These reduplications were regularly used by my respondents for emphasis.

\section{Operationalisation: inauthentic/authentic}

'Authenticity is born out of fakery' (Lindholm 2002).

'... it is Disneyland that is authentic here!' Jean Baudrillard (1989: 104) states, implying that authenticity is the artifice, while cinema and television are the reality of America. The 'real' America is to be discovered underneath all that veneer. Authenticity is a gloss of a the nation that is really about ghettoes, trailer parks, pink flamingos and middle-class lawns covered with Christmas décor. Slavoj Žižek (1991) contends that the search for the 'authenticity' of objects, and I suppose subjects, is actually a pseudo-problem. If these social and cultural artefacts are fabrications, why bother to investigate their authenticity? This view, which suggests that authenticity is simply a by-product of the constructed-ness

\section{https://repository.uwc.ac.za/}


of the world, is echoed by others. For Benjamin (1969), the exactness of artifice is what endows many of the objects in the present era of 'mechanical reproduction' with their authenticity. Authenticity is only possible, he argues, once the technologies that allow art to be mechanically and exactly reproduced have been invented. This line of argument, which associates authenticity with an event (for Benjamin, the invention of particular technologies), places authenticity within the historical (Shiner 1994). Authenticity can only be spoken of within a context that recognises its artificiality and the historicality of its emergence, and it is within this frame that it should be read throughout the article.

Adorno (1964) suggests that 'the authentic', as asserted by the existentialists of his day, was not a desirable position. He therefore avoids the essentialist, autochthonous and purist tendency that authenticity suggests (Paddison 2004). If these are the trends and ends of authenticity (referring to Heidegger; fascism, racism, Auschwitz), they are inauthentic as a matter of principle and as a reflection of 'actual humanity' (Adorno 2003; Paddison 2004). This reference to 'actual humanity' is key for the study of the San, because this is what many philosophers sought to arrive at, and what I refer to as prelapsarian.

What about the copy that is more real than the thing it copied? This is a copy so exact as to defy any attempt to de-authenticate it. A question I continually asked myself was how portrayals of the San (of themselves by themselves, as well as the portrayals tourists want to see) can be so completely textbook? How is it possible that the acts, stories, tools, materials and objects that I saw during the first few years of the 21st century were the exact same as those I had seen in my school textbooks and in popular (and, I may add, discredited) portrayals of the San? We have to return to Žižek's (1991) point about the nature of the problem. It seems that authenticating is not the real problem here, but rather an investigation of the conditions (discursive, historical and so forth) in which authenticities are produced.

\section{Authenticity as cultural purity}

Most of my research participants realise that their 'culture' is less than 'pure'. They know and acknowledge that some of their cultural rituals and performances are recreations. Many admit that they have 'lost their culture' or 'forgotten the old ways'. While many realise that claiming an original bushman-ness which has a perfect congruence with groups that once existed is futile, the action space that is the land claim requires that they make some declaration of such an ethnic identity, even if the identity is simply 'approximate'. Few $¥$ Khomani assert an authenticity based on what I call 'cultural purity', which is here taken to mean traditional isomorphism, historical similitude, mimetic credibility (Bruner 1994; Gable and Handler 1996; Handler and Saxton 1988) or ethnographic authenticity (Carrier 2009).

If few $¥$ Khomani San can claim that their lifestyle matches that of a people who were in the past differently referred to as San, Boesman or Bushman, how do they claim such an identity in the present? It would seem they selectively draw on a few easily reproducible traditional, historical, mimetic or ethnographic traits. No one individual can, however, draw on these traits in an all-inclusive manner: perfect equivalence is only possible for the 
simulacra (see later). Let me illustrate this awareness of the limits of authenticity as cultural purity through a brief ethnographic interlude.

Oom Hans Tieties had been a municipal worker all his life, before taking early retirement and investing his pension in a herd of sheep and a few goats. He became a member of the $\neq$ Khomani San Communal Property Association (hereinafter CPA) ${ }^{11}$ and grazed his animals on CPA land, the same that the $\neq$ Khomani had won in the land claim. As a livestock farmer his lifestyle was seen as antithetical to a way of life thought of as 'San'. I was often told, in reference to Hans, that 'real San people hunt, they do not farm'. In addition to his livelihood strategies, salaried work and farming, Hans spoke neither Nama nor $\mathrm{N} \mid \mathrm{u}$ - the two languages that fewer than 40 individuals of the $¥$ Khomani San claim to speak. Dawid Kruiper spoke a smattering of Nama (widely considered to be a language of the Khoi pastoralists of Namaqualand and southern parts of Namibia). Other individuals who spoke $\mathrm{N} / \mathrm{u}$ were regarded as San, because theirs was understood to be the lost language of the San of the region. That Kruiper spoke Nama led many to question his legitimacy as a bushman, and some even suggested that he did not hail from this part of southern Africa. These commentators noted that Kruiper's ancestors had arrived in the southern Kalahari around the early 2oth century as refugees from the German wars in Namibia (Grant 2011). Nama or $\mathrm{N} / \mathrm{u}$ is thus used to determine whether or not an individual is autochthonous to the region.

Oom Hans did not participate in any cultural performances for tourists because of his relative wealth ${ }^{12}$ (inter alia and in contrast to other CPA members he owned a vehicle and lived in a formal brick home at Klein Mier). He was considered by many other $¥$ Khomani as less authentically San. He would often tell me he was aware that his lifestyle did not reflect actual San characteristics. He was not alone in this: many other łKhomani were unable to base their claims to San-ness on any of the constitutive mimetic characteristics that many argued constituted 'true bushmen-ness'. Many who did not display or perform a mimetically credible bushman script were called westerse Boesmans (western Bushmen), because their way of life reflected what was considered to be a 'modern Westernised' lifestyle, and did not adequately mirror that of the bushmen (see also Simões 2001). San livestock farmers faced a very particular dilemma: they had to show that they were regte Boesmans and that they had as much claim to San-ness and the available resources as those $¥$ Khomani who could claim ethnographic authenticity.

How did these San farmers show that they were regte (real) or ware (true) San? They could not claim to follow the traditions of San people; after all, their workaday lives did not match up with those who were considered bushmen. These farmers could make reference to being San through an appeal to authenticity as existential veridicality. They could claim they had in fact been 'marred by modernity'. Several suggested to me that they may have had a true bushman story, had their lives not been interrupted by modernity/modernisation. Oom Hans and others like him claimed they were 'regte Boesmans' because of a shared history of dispossession and violence experienced at the hands of Europeans and other groups. Thus, the claim was that the 'modernising' project of colonialism (and subsequently, apartheid) had alienated, made anomic, and burgeoned their alterity. 
Oom Hans reported that they 'have lost the names and the way of life and the land and its resources and for years lived on the bottom of the heap'. For these farmers, participating in the land claim was not an ordinary reclamation of some 'auratic' identity (Mufti 2000) - in fact, they had never known such an identity. They were, however, seeking redress for the alienation, anomie and alterity of modernity. They were asking us to believe that they were San farmers, even though the notion of being both a farmer and a San seemed antithetical. Moreover, since they had no recourse to cultural purity or tradition in order to define themselves as San, these farmers made claims to their San-ness through appeals to the common dispossession, domination and destruction of their traditional culture by 'forces of westernisation'.

\section{Authenticity as an existential question}

The example above shows that authenticity as cultural purity is closed off to some people who need recourse to a different type of authenticity. Authenticity is not so much a matter of showing that their life conforms to some perceived form, but that it at least reflects a 'rightly guided' life, especially within the 'modern age'. First, authenticity becomes a moral question; second we are reminded of authenticity as a modern phenomenon; and lastly as an attempt to make this version of authenticity seem critical, occidental claims are deployed to validate these accounts. In addition, when authenticity is described as existential veridicality it helps us understand why the San and the Kalahari are visited by what I broadly refer to as 'new age seekers'. Claims to, and assertions of, authenticity are sometimes made on moral grounds. Here the human agents appeal to a sense of a rightly guided, ethically informed, self-aware life. The research participants, who are often characterised as less culturally pure (i.e., less authentic) most commonly use these normative statements to construct the authenticity or inauthenticity of the more 'culturally pure'. Let us see how this plays out in the field.

One small extended family group who are in key leadership positions in the CPA, the Eamons, are regularly de-authenticated by the tradisie Boesmans. The latter, under the leadership of the late Dawid Kruiper, would regularly claim the Eamons were not real San because they refused to participate in cultural tourist activities where participants were in states of undress. The Eamons wore Western clothes, went to church, spoke Afrikaans, drove modern vehicles and, above all, engaged in economic activities that were not 'San' (like farming, wage labour and other business). The Eamons countered these deauthenticating claims with a similar set of declarations, arguing that Oom Dawid and the tradisie Boesmans were unfairly at the forefront of community activities, despite the fact that they were allegedly often drunk, unruly, smoked marijuana or had relaxed morals, etc. For both 'camps' authenticity was not simply about being culturally correct: both the tradisie Boesmans and the westerse Boesmans held the notion that being San was also about a set of normative principles.

Tradisie Boesmans argue that westerse Boesmans have betrayed the idea of what it means to be San, and that their resistance to this ideal (even if we recognise it as the simulacral bushman) serves as evidence of their lesser bushman-ness. The deauthentication is thus an admonition for their perceived betrayal of their culture by the westerse Boesmans and thus a moral issue. Conversely, since the authenticity of the tradisie Boesmans is established through a hegemonic mimetic credibility, the westerse 
Boesmans mostly de-authenticate with references to normative sanction and claims of unethical and un-Christian behaviour.

One of the single most influential principles in earlier literature about the San (especially that produced after the 1950s) is the idea that egalitarian principles lie at the foundation of all San societies. Some argue that this manner of representing San society largely resulted from a critique of Western industrialised capitalist society of the post WWII era (Wilmsen 1995). The values found in San societies represented the way life should, and could, be and also what the Western world had 'lost' (Wilmsen 1989). The construction of San identity through the 'critique of the modern' persists today, albeit outside of academic circles. My argument is that authenticity in San culture is constructed by 'outsiders' through the lens of Occidentalism (Chanock 2000; Rabinow 1986). Others have characterised this concern for authenticity as a characteristically 'modernist anxiety' (Gable and Handler 1996).

Authenticity and its anxieties emerge in a particular historical context. While not all theorists have as confidently attributed its emergence as a concern to a particular moment as does Benjamin (1969), most agree that the trope of authenticity is modern (Baugh 1988; Berman 1970; Gaugnion 2004; McCannell 1973; Tomaselli 2001; Trilling and Trilling 2009). This does, however, suggest something very specific about the 'presence' of authenticity in what I heard spoken about in the field. If these thinkers are correct, and authenticity is a phenomenon resulting from a particular set of social and cultural markers of this stage in the development of capitalist culture, what then of the $\neq$ Khomani among whom these concerns are constantly expressed and addressed? Well, it places the $\neq$ Khomani firmly in the culture of the present! Their attempts to assert an authenticity can now be read as efforts to participate in the local and global political economy as astute players who are an actual part of the here and now, and not simply temporal misfits.

Elsewhere I documented extensively authenticity as a concern with the maladies of modernity (Ellis 2010). It may suffice to note one or two brief examples. The first idea is that the practices of the San somehow reflect sound conservation strategies. My $\mathrm{PhD}$ thesis extensively discusses how the harvesting of firewood by the $\ddagger$ Khomani San was used a means of drawing a distinction between tradisie Boesmans and westerse Boesmans. Further, this split between the two groups is framed by discourses of good and bad environmental management strategies linked to their degree of westernisation.

The tradisie Boesmans repeatedly raised concerns about sound environmental management and living in harmony with nature. For them, a major factor that ensured entitlement to resources (the land) hinged on the continued ability of the individual to seat themselves within nature. Those who claimed San identity but had little interaction with nature were seen as suffering from so-called 'cosmological autism' (Kohn 2007: 9). In this view, a person can easily lose the ability to interact with or live within a particular domain and have aspects of that domain completely closed off to them. Some $¥$ Khomani felt it was not enough to be able simply to call oneself San or Boesman. Rather, the individual had to retain a way of being, in order to be San, that firmly seats them within nature. The so-called westernised San were often categorised in this way by 'traditional San', who saw their westernised 'cousins' as outside their own eco-cosmos, because they

\section{https://repository.uwc.ac.za/}


had lost the ability to live in or with nature, the plants and animals found in their world of objects and subjects.

Another example of efforts to use Bushmen authenticity as a remedy for the maladies of modernity is the hope of recovery, a nostalgia for the past, and the varied calls for a return to source, i.e., 'auratic critique' (Mufti 2000: 88). Auratic critiques pertain to an object that is only accessible as an aura as a glimmer from the past. This epitomises the postcolonial moment, the rueful longing for an unrecoverable past, and the postcolonial as that which has been insufficiently mourned (Spivak 1999). These hopes of recovery are especially evident in attempts by the łKhomani to recreate the way of life of the 'real Bushmen'. My fieldwork was filled with one lament after another about the lost way of life. Such laments recall these auratic elements, those supposed aspects of San life that made it such a 'wondrous thing'. These elements of an imagined San past are offered to the $\neq$ Khomani as an apparent treasure trove of development and livelihoods by government and NGOs. The challenges of authenticity and the failure of plans to use auratic cultural models as a means of making a living are typical of postcolonial subjects.

\section{Authenticity as circulating value}

Where authenticity operates as a question of value it is viewed by those who buy into it as part of an economy of cultural politics in which signs, as measures of value, circulate for the production of cultural commodities. Authenticity in this economy often draws on simulacra and cultural relics of dubious origin, and represents some of the clearest examples of Spivakian post-coloniality. This is a state of being where the colonial past paralyses the agents and keeps them living in a moment after the end of the anti-colonial struggle. The $\neq$ Khomani reminisce and their recollections are ripe with nostalgic imagery. The simulacral bushman is offered to the outsider and to the world as a commodity, but the world is suspicious (see Dyll-Myklebust 2007). Some tourists, journalists, farmers, neighbours demand to know: Is this a 'real' Bushman, am I not buying a fake experience or thing?

It is telling of what the Other is aware of. Dawid learned over the years of interaction with researchers, information gatherers, tourists and the like, what kinds of information would be interesting to them - something like a beetle picking lice out of a child's hair - and he was able to offer this information on the spur of the moment. This is an intuitive ability to offer up types of stories to researchers. There are no vestiges of ancient traditions here, except those that are drawn from the simulacra to please global audiences. People travelled great distances to consult Dawid on matters herbal, medicinal and magical. ${ }^{13} \mathrm{He}$ and his father and those around him shaped and sustained a micro-political economy one that plays with nature, ecology, culture, magic, myth, fantasy and reality. Ersatz political economy or not, there is at least the germ of a small market in bushman-ness in the southern Kalahari that the $\neq$ Khomani have tried to grow.

The łKhomani have turned bushman-ness into work, they have tried to make it pay, and they have tried to sell it on the open market. A key point in this genealogical reading is that attempts to commoditise bushmen-ness have almost always been mediated by outsiders like philanthropists, entrepreneurs, tour operators and NGOs. Such mediation has drawn on readily available stereotyping and racist iconography of the San, which

\section{https://repository.uwc.ac.za/}


include popularly held perceptions about San bodies, culture, habits and language. The commoditisation of bushman-ness in this mediated form is seldom questioned, and its authenticity seldom interrogated. However, when the ¥Khomani obtained their own land and began to replicate mediated ventures like those that used to be managed by outsiders, consumers consistently questioned the authenticity of the enterprise.

Why do consumers question the San in their production of bushman-ness, but not the mediated undertaking? First, the desire for authentic experience is exactly what tourism delivers (Cohen 1988; McCannel 1973). McCannel (1973) argues the tourist is actually satisfied to purchase a 'performed experience' and may be completely aware of the contrivance. $\mathrm{S} / \mathrm{he}$ is fine with experiencing an essentially fictional (can we say inauthentic?) encounter, as long as they know it is staged. Instead of focusing on establishing authenticity, anthropologists should be examining the processes through which 'authenticity is made' (Cohen 1988). In Erik Cohen's view authenticity is established through the imposition of subject distance between the tourist and commoditised culture; the greater the distance, the more authentic the experience even if it is an obvious contrivance. The example offered is of the conspicuousness of cash transactions. Exchange is usually handled through booking offices or administrators, thus tourists do not feel they have paid for something. The unmediated łKhomani tourist interactions often involved direct exchanges of money between the San and visitors. Tourists and outsiders on occasion felt that the łKhomani were begging or were somewhat forceful when they suggested payment for photographs or offered crafts for sale on the roadside. In these encounters very little subjective distance is placed between the San person and the tourists, who are confronted with very real human realities: money, food and poverty.

Another connection can be made to the existential take on authenticity, namely that of scripting one's own story or narrative employment (Baugh 1988). The imposition of 'subject distance' in the touristic encounter allows tourists to produce their own narrative, to have their own reading and thus create their own particular sense of authenticity. It is as if the production of authenticity is a carefully choreographed interaction that should not be forced onto the tourist but rather offered tentatively, in snippets, so as to not spook him/her.

A crude formula can be proposed from Cohen's argument; the more subjective distance the more authentic the experience seems (note experience). Conversely, the fewer attempts or the less successful the attempts at creating subjective distance are, the more the tourists see the people, their needs, their poverty, their misery and their humanity, and this mars the touristic experience. After all, tourism is about an exotic experience that allows tourists to escape the realities of everyday life that they leave behind in Europe and elsewhere. During these unmediated tourist encounters, observers confront the inauthentic directly. The inauthentic reminds us of the rawness of the lives of the rural poor. Visitors who question the authenticity of the encounter are not querying the cultural purity of the San, but rather the people-ness. They do not see bushman but they see the rural poor, ${ }^{14}$ they see the sick elderly, they see single mothers living with grandparents who have to support their great grandchildren. I ask the readers to ignore the simple aesthetic perfection of the bushman and spend a moment considering the raw life of the 
various rural poor who inhabit and have moved to Witdraai and other farms in the Mier area, hoping for relief from their hardships and poverty.

\section{Struggle for the real: the methodological problem of authenticity}

Clifford Geertz (1971) raises a concern about the efficacy of anthropological methods in studying religion. Participants know that we are concerned with a subject like Islam, and whenever they encounter us as researchers, they don their Islamic identity. Geertz's question is the following: When are we as anthropologists watching a performance and when are the actions of the 'Other' 'real' or authentic? For Geertz it is not merely the interference of capital and modernity in the lives of the non-Western world which leaves us as anthropologists with mere remnants of former cultural glories to study in our far-off research sites. In the end, our ethnographies produce nothing more than accounts that reflect only what Benjamin (1969) terms an aura of authenticity, where every time an object is reproduced it only retains some minor semblance or aura of the original object. Nor is it simply a question of witnessing and capturing an uncorrupted, pure portrayal of non-Western culture, a sort of fossilisation and museumisation of 'people'. Rather, authenticity should be a central methodological concern for anthropologists. In part, Geertz suggests that it is useful to know how deep these identities penetrate into the 'being' of humanity. The 'struggle for the real' or for authenticity, in the Geertzian sense, means being able to penetrate this methodological veil and to decode the cultural.

In addition, it should be acknowledged that the presence of anthropologists impacts on the roles research participants choose to play. Put differently, our presence as anthropologists force participants to constantly wear their 'anthropological subject' hats. When do these real people emerge without their subject hats, or does our presence always keep our subjects in character? The ethnographic method suggested by Geertz has to be able to see beyond this character that the Other acts out in the research encounter.

In this last instance I offer a scene from Arundhati Roy's (2002) text, God of small things, to further illuminate what Geertz might have been after. In the passage two of the main protagonists, Rahel and her twin brother Estha, approach a temple to watch a performance of the kathakali. ${ }^{15}$ The narrator tells us that this particular temple is off the usual tourist routes and holds no significance other than its lack of audience. The performers come to placate their gods and ask forgiveness for encashing (sic) their religion/culture. The sense one gets from this scene is of a group who wish to practise their religious and cultural rituals earnestly, not for the voyeuristic touristic performances they have become. 'On these occasions, a human audience was welcome, but entirely incidental' (Roy 2002: 229). Geertz, in my view, wants this culture to be revealed; he wants these 'audience incidental' moments to be made clear by the ethnographic endeavour. I wonder whether the San ever wait for occasions where human audiences are incidental. Below I recount an incident that reveals the aversion to the audience and the Other's engagement with it.

In the last two decades the San, and more so the łKhomani, have been overrun with researchers from a variety of disciplinary backgrounds: natural, agricultural, nutritional, social sciences and humanities. The $¥$ Khomani often told stories of, and described, the research encounters they had with researchers. On occasion some of these stories were 
told so as to ridicule researchers and the type of activities their research included. Kruiper often tells about various controls involved in experiments like only eating this or that bread, or only eating a particular maize meal, or of having to collect stool samples from his grandchildren. The San's accounts of researchers offer an unusual lens into how our efforts as researchers were interpreted and perceived by participants. What was related to me usually suggested that there may be problems with the data that were collected, that the participants were deceptive or may have been actively misleading. For me, the issue was the authenticity of the data. There is another way of reading it, however; the participants are actively scripting the ethnographies of their lives.

Abraham, in those days Dawid's frequent companion, occasionally asked me to interpret for him on guided walks through the San farms. One such tour ended at Dawid's house. I was sitting in his yard, where one of his grandchildren was playing nearby. I saw a toktokkie (darkling beetle/Tenebrid beetle) crawling across the sand and Dawid saw me watching it. He said: 'This beetle, you know, we use it to get rid of lice in children's heads.' He scooped up the beetle, put in the hair of the child, and walked off to a nearby fence in his limping gait. At first the child did not realise that a beetle was in her hair, but as soon as she felt it crawling she was startled by the sensation (she became suddenly wide eyed) and frantically brushed it off. Dawid laughed, looked away, the child ran off to find her mother.

Is the beetle really used to pick lice from children's hair? I seriously doubt it! Tenebrid beetles only eat detritus, they are not active predators that hunt, they are scavengers. I know Dawid to be rather mischievous and his reaction to the scene that played out suggested that he was making it up, his tell-tale laugh and his aloofness after the child had run off, left the impression that he had been caught out.

Several aspects of this story are significant to the arguments about authenticity. First, the story points to the way in which authenticity is constructed out of extraordinary elements - a beetle becomes a medium though which to read bushman-ness, it feeds into the simulacral bushmen. Second, the methodological aspects of doing work among these heavily researched communities are highlighted; these communities have been extensively researched by the Centre for Communication, Media and Society (CCMS), and I will not attempt to cover those methodological strategies and debates. The argument here focuses on two particular processes: that of withholding (Spivak 1990) and that of 'common ontological unfolding', which often happens in the anthropological research process (Ramos 1992).

\section{Deepening anthropologies: hyper-reflexivity and research intimacies}

As a point of departure and because it speaks to some of the issues I want to offer as a conclusion, let us briefly mention some of the work by done by CCMS in the southern Kalahari. The research done by a long succession of students since the early $1990 \mathrm{os}$ highlights two invaluable sets of contributions: the first results from attempts by CCMS to develop 'a hyper-reflexive ethnographic methodology' (Kapoor 2004). Hyper-reflexivity is a method of engagement derived from Spivak's 'problem of the native informant'. ${ }^{16}$ The resolution of the 'problem' is to be found in an 'obsessive interest in self reflexivity' in which anthropologists are aware that they are 'intimately inhabiting and negotiating 
discourse' in order to 'produce a non-hierarchical encounter with the other', and ultimately to make anthropological and all research 'engagement more accountable to the subaltern' (ibid). Examples of the methods used by the CCMS include auto-ethnographic work (see Tomaselli 2003, 2005, 2012; Tomaselli et al. 2013), 'campfire ethnography' (McLennan-Dodd 2003), and fieldwork friendships (Dyll 2003; Mhiripiri 2012).

The second set of methodologies can be classed as a series of ethnographic experiments that include not just a 'classic ethnographic approach' (here rather crudely understood as extended field stays and mixed methods), but also a range of other ethnographic elements linked to methodological concerns. The research efforts by CCMS are diverse and appear haphazardly organised or based on students' whims and preferences. These include: the production of ethnographic film, multi-vocal epistemologies (Dyll-Myklebust 2013), narrative analysis, semiotics (Tomaselli 2001a), tourist analyses (Barnabas 2010; Peters 2013; Tomaselli 2011; Wang 2001), art studies (Barnabas 2010, Finlay and Barnabas 2012; Lange et al. 2013), and rock art studies (Tomaselli 2001b). I mention here also that the work of Shane Moran (2009) and Michael Wessels (2010) has equally attempted to shift the boundaries of San scholarship, albeit through the deployment of different literary, textual, translation and theoretical strategies. The aforementioned falls under a Derridadean critique that attempts to re-read the San archive in relation to the nostalgia for the lost origin (Wessels 2010). Overall, the mainstay of San studies is, for the most part these days, grounded firmly within a tradition of critique that aims to transcend what has been problematic in this body of scholarship.

In short, cumulative CCMS accounts have produced a meta-anthropology (an anthropology of anthropology) and a range of other techniques I call 'research intimacies', i.e., attempts at closing the subjective, epistemological and other gaps between researcher and researched (see Jeursen and Tomaselli 2002; McLennan-Dodd 2004). For all its seeming arbitrariness these diverse engagements have responded to an epistemological problem of studying the San and the range of representations as well as engagements and how these encounters have produced particular 'knowledges'. Moreover, the research has also responded to issues beyond epistemology. I argue that epistemology does not adequately capture the problematique of anthropology. What the work of some of these researchers contends with, is that they operate in a common dialogic process of revealing each other's most basic being. The question of a deeper anthropology is not simply: How do I get to know who you are? The more fundamental question of anthropology is: Who are you and who am I? (see Tomaselli 2013, in response to a critique of CCMS's reflective/reflexive position offered by Hitchcock and Biesele 2008).

\section{Anthropologising the self and common ontological unfolding}

The longitudinal aspect of the CCMS ethnographic encounter, together with its very serious consideration of the 'epistemic violence' (Ayotte and Husain 2005) the San have been subjected to through years of being studied and talked about in the West, creates a unique opportunity (read ethnological database/archive) that will allow us to 'anthropologise' not just the Other, but also Western epistemic travellers (researchers, journalists, media, tourists, government agents, NGO workers, etc.). For Rabinow (1986) the call to 'anthropologise the West' is an attempt to turn the gaze of the West and to use anthropology to problematise and interrogate the role of the West in constructing a non-

\section{https://repository.uwc.ac.za/}


Western subject. However, anthropologising the West does not mean the simple production of an Occidentalism; it is rather a dialogue. Agamben (2004) speaks of the 'anthropological machine' - a particularly Western epistemic undertaking that creates an ethnological subject by granting it an externally imposed ontological status. The CCMS engagement offers a meta-anthropology that anthropologises bushman studies, the San and bushman students, by turning gazes and asking how the ethnographic subject is, in turn, created by the gazes.

I conclude with a question, a line of inquiry, a problematique. Why is the abovementioned methodological and meta-anthropological work necessary? Two aspects of my own ethnographic encounter and search for an authenticity stand out. The first is what I can best describe as following a process of 'withholding' on the part of the Other. Such withholding is the retreat of the other, our anthropological subject is withdrawing and our efforts to represent it clearly and even in a critically deconstructed state seem increasingly unlikely. Baudrillard (1998) alludes to the self-same resistance to representation by the Other or to a retreating Other.

Is this the now-familiar crisis of representation? Not quite, but this crisis does figure in the resistance/withholding. Withholding is not the simple catachresis, the continued use of concepts without real-world referents, as highlighted in the work of Spivak in her engagement with postcolonial theory. This is not the Western knower misjudging the exact identity of the Other through the misapplication of concepts and ideas. No, what I am conceptualising here is an active process undertaken by the Other, and its victim is not the Third-World postcolonial subject, but rather the Western European self. What I am dealing with here is the refusal to be represented, noted in literary characters such as Friday in J.M. Coetzee's Foe (1986). In Coetzee's text Friday eludes all attempts to represent him, the best that those who encounter him can do is hazard a guess.

In the field I often encounter people unwilling to speak to me or other researchers. Various 'strategies' are employed to resist or withhold participation, for instance, Pooi, the grandson of one of the last $\mathrm{N} \mid \mathrm{u}$ speakers, would often shout loudly at journalists and filmmakers and threaten to lock the gates of the farms and not let anybody in. When I asked him about this he complained that 'everyone keeps coming in and taking their knowledge but bringing nothing back', and for this reason he refuses to participate in research and dislikes it when his mother or grandmother participate. On other occasions I noticed some San 'pretending to be drunk' in order to avoid researchers. Some are rude to researchers, others ask for large sums of money. Attempts were also made by organisations and legal representatives to limit and shape the contours of interaction with the San. The South African San Institute (SASI) drafted legal contracts that set out the terms of contact between the San and journalists, media, film makers, researchers, farmers, tour operators and the like. In an effort to enforce these contracts and their terms, the San people were asked to not participate in any research, nor to allow anyone to photograph them. Literally, this meant there was sometimes an actual silence, a reluctance to speak, but in addition to this the San and SASI thought it useful to also impose a visual absence or silence. 
One of the most telling entanglements in this regard was the suicide of Dals in late 1999. Dals took his own life by jumping in front of a bus filled with tourists. I read this event as an attempt on his part to remove himself from the equation of representation. His suicide was a last-ditch attempt to place himself outside the grasp of an externally imposed representation. He took his own life, he placed himself in the path of the tourist bus; in my view he took back his voice and in the final act represented himself and wrote his own story in a classic existentialist move.

Withholding on the part of the Other is a process that complicates the production of an authentic ethnological subject. Anthropology among the San in the southern Kalahari is not experiencing the limits of a paradigm or a scientific consensus that can no longer explain what it is observing without creating a new, conceptual technical toolbox. Rather, we are witnessing a shift in the agency of the Other, who no longer behaves like a willing and docile research subject. We are now confronted with a self-asserting, sometimes silent, sometimes hostile, retreating other.

Let me return to a point made in passing at the beginning of this text, where I noted that the prelapsarian 'Other' eludes us all the time and if we do not find the authentic, then anthropology seems pointless. Barriers (theoretical or methodological) do not seem to offer a ready way out. I have suggested a deepening anthropology (e.g., work done by CCMS), but I intuitively sense I may need to offer a different solution. The reason for this is that the problematic is not simply a theoretical issue of how the Western episteme interrogates or constructs an authentic view of the other. Far beyond this, the retreat and withholding by the research subject shows that the challenge for bushman scholars is located in both worlds, that of a Self and an Other. Once this realisation sinks in, then the parties involved can begin to tackle the problem not as a characteristic of this world or that world, but rather as an issue of 'common ontological unveiling' (Ramos 1992). Some of this is suggested from the field by research activities that are hyper-reflexive and intimate of the CCMS, and also by other ethnographic tidbits like 'lice-eating beetles', by withholding. In the end these suggest that any failed attempt at locating the authentic is a failure to locate not just the Other, but the Self as well. 


\section{Notes}

1. The discussion that follows is based on ethnographic fieldwork I conducted between

2. People's Movement for the Liberation of Angola.

3. My supervisor notes that the 'fear', as much as it was real, was also drummed into the heads of the soldiers in these battalions by the SADF.

4. The communities, now living in Platfontein, $15 \mathrm{~km}$ from Kimberly, have recently become the focus of extensive research by students from the University of KwaZulu-Natal. See Barnabas (2010) on art-making; Mhlanga (2006) and Hart (2011) on radio and Dockney (2011) on storytelling via video.

5. Here preservation is employed as it was used by members of the 'Preservation Committee' that is to have measures in place to preserve the culture, ways and lifestyle of 'a people'.

6. The reclassification of Bushmen as coloureds and no longer native means they do not need to be catered for as with other 'native' groups. Importantly, the state need not cater for their land needs; in terms of the policies of separate development the native must ideally be provided a homeland. From sources we see that the successive governments did not view a San-tustan as a possibility.

7. For more on the San homeland proposed in the 1930s, see Gordon (1995) and Boydell (1948).

8. I am not suggesting that the mere assertion of San identity is enough to cause its re-emergence: the identity is not simply voluntaristic, rather 'authenticity' is at once volunteered but needs other elements which are not solely the body (race elements), nor are they simply ethnic (culture elements).

9. The Afrikaans term 'Baster' literally translates as a bastard, but when applied to animals it can denote a cross breed, or when applied to dogs, a mutt. In earlier uses of this word, it referred to people who were first-generation offspring of a white male and a slave/indigenous woman. These persons occasionally enjoyed greater privileges than other slaves, but the laws of the colony became increasingly oppressive and many Basters left to farm beyond the frontier. Today the term is not widely used and seems to be confined to regions of the Northern Cape and the southern parts of Namibia. In the context of present-day Mier, it has gained more currency as an economic status category than a racial one. Bredenkamp (1991) suggests that the term 'Khoisan' be applied even to those who are historically termed Basters or Bastaards.

10. The example of painting is one also by Benjamin in his 'Mechanical reproduction'.

11. The CPA is a common property institution that allows groups (in the South African case, beneficiaries of land redistribution or restitution) to hold land as a juristic person. CPAs generally have defined membership based on various criteria, such as common dispossession or in the case of the ¥Khomani San, bushman-ness. CPA members elect an executive committee and other constituent bodies to govern the resources of the association.

12. I participated in wealth-ranking exercises with the extension workers of FARMAfrica. For some of the results see Bradstock (2006, 2007).

13. I have personally encountered a number of Xhosa-speaking people who had travelled from the Eastern Cape or Cape Town to visit Dawid Kruiper or one of his relatives. N/ooi (Dawid Kariseb) also receives many visitors from various regions of South Africa. 
14. The 'rural poor' are probably as much a simulacrum as 'bushmen'. It is a matter of which simulacrum serves the people at any given time.

15. Dance dramas enacted from the holy texts reflecting the life of Lord Krishna, over 100 variations of these plays exist.

16. The 'problem of the native informant' is not a problem of the 'other'; rather it is an epistemic question and a representational issue. Simply put: Who speaks for the 'other'? Who is responsible for giving the world its image of the 'native' who is the recipient of assistance, of 'development'? Very often it is indigenous academics, intellectuals who speak to the 'West' about the subaltern, and these intellectuals are equally complicit in creating particular images of the other as impoverished, racialised, indigenised, etc. Hence, the problem of the native informant speaks back to Spivak's text 'Can the subaltern speak?' and its conclusions. 


\section{References}

Adorno, T. 1964. The jargon of authenticity. USA: Routledge and Kegan Paul.

Adorno, T. 1987. Minima moralia: reflections from damaged life. London: Verso.

Adorno, T.W. 2003. Can one live after Auschwitz? A philosophical reader, ed. R. Tiedemann. Stanford: Stanford University Press.

Agamben, G. 2004. The open: man and animal. Stanford: Stanford University Press.

Barnabas, S.B. 2010. Picking at the paint: viewing contemporary Bushman art as art. Visual Anthropology 23(5): 427-442.

Barnard, A. 1990. 'Comment' on foragers, genuine or spurious? Situating the Kalahari San in history. Current Anthropology 31(2): 109-146.

Baudrillard, J. 1989. America. New York: Verso.

Baudrillard, J. and P. Petit. 1998. Paroxysm: interviews with Philippe Petit. New York: Verso. Baugh, B. 1988. Authenticity revisited. The Journal of Aesthetics and Art Criticism 46(4): 477-487.

Benjamin, W. 1969. Illuminations. New York: Schocken Books.

Berman, M. 1970. The politics of authenticity: radical individualism and the emergence of modern society. Boston: Atheneum.

Biesele, M. and R.K. Hitchcock. 2008. Writing in the San/d: autoethnography among indigenous southern Africans - a review. Collaborative Anthropologies 1(1): 201205.

Biesele, M. and R.K. Hitchcock. 2010. The Ju/'hoan San of Nyae Nyae and Namibian independence: development, democracy and indigenous voices. New York: Berghahn. Boonzaier, E. and J. Sharp. 1993. Staging ethnicity. Track Two 10-13, February.

Boydell, T. 1948. My luck's still in. Cape Town: Stewart Printers.

Bredenkamp, H.C. 1991. Die Khoisan en vakterminologie na The Oxford history of South Africa: 'n Historiografiese dilemma. South African Historical Journal 25: 61-76.

Bruner, E. 1994. Abraham Lincoln as authentic reproduction: a critique of postmodernism. American Anthropologist 96(2): 397-415.

Bruner, E. 2001. The Masaai and the lion king: authenticity, nationalism and globalization in African tourism. American Ethnologist 28(4): 881-908.

Carrier, J. 2004. Ecotourism and authenticity. Current Anthropology 45(4): 483-498. Carstens, P. 1966. The social structure of a Cape coloured reserve. London: Oxford University Press.

Chanock, M. 2000. 'Culture' and human rights: orientalising, occidentalizing and authenticity. In Beyond rights talk and culture talk, ed. M. Mamdani, 15-36. Cape Town: David Phillip.

Clifford, J. and G.E. Marcus, eds. 1986. Writing culture: the poetics and politics of ethnography - experiments in contemporary anthropology. Berkeley: University of California Press.

Coetzee, J.M. 1986. Foe. South Africa: Penguin.

Cohen, E. 1988. Authenticity and commoditization in tourism. Annals of Tourism Research 15(1): 371-386.

Comaroff, J. and J. Comaroff. 1999. Occult economies and the violence of abstraction. American Ethnologist 26(2): 279-303.

Comaroff, J. and J. Comaroff. 2009. Ethnicity, Inc. Chicago and London: University of Chicago Press. 
Crawhall, N. n.d. Too good to leave behind: the $\mathrm{N} \mid \mathrm{u}$ language and the $\ddagger$ Khomani people of Gordonia district. Unpublished manuscript.

Den Hertog, T.N. 2013. Diversity behind constructed unity: the resettlement process of the !Xun and Khwe communities in South Africa. Journal of Contemporary African Studies 31(3): 345-360.

Derrida, J. 1972. Limited, Inc. Chicago: University of Chicago Press.

Dockney, J. 2011. Social power through self-imaging in participatory video. Unpublished Master's dissertation, Centre for Communication, Media and Society, University of KwaZulu-Natal.

Douglas, S. n.d. Do 'Bushmen' belong in reserves? Reflections on recent events at Schmidtsdrift and anthropological intervention. Unpublished seminar paper delivered in Social Anthropology Dept., University of Cape Town.

Douglas, S. 1995. The human isthmus: dangerous diluted sewerage poison; recuperating 'bushman' in the new South Africa. Critical Arts 9(2): 65-75.

Dyll, L. 2003. In the sun with Silikat. Current Writing: Text and Reception in Southern Africa 15(3): 135-150.

Dyll-Myklebust, L. 2013. Development narratives: the value of a multi-voiced epistemology in Kalahari research. http://www.inter-disciplinary.net/probing-theboundaries/wp-content/uploads/2013/05/Dyll-

Myklebust.pdf(accessed14March2014)

Ellis, W. 2010. The łKhomani San land claim against the Kalahari Gemsbok National Park: requiring and acquiring authenticity. In Land, memory reconstruction and justice, ed. C. Walker, T. Kepe and A. Bohlin, 181-197. USA: Ohio University Press.

Erasmus, P.A. 1997. The harmless people: from Stone Age hunter to modern soldier. South African Journal of Ethnology 20(4): 165-169.

Feuser, W.F. 1988. Wole Soyinka: the problem of authenticity. Black American Literature Forum 22(3): 555-575.

Finlay, K. and S. Barnabas. 2012. Shifting representations of the Bushmen. In Cultural tourism and identity: rethinking indigeneity, ed. K.G. Tomaselli, 24-71. The Netherlands: Brill.

Geertz, C. 1971. Islam observed: religious development in Morocco and Indonesia. Chicago: University of Chicago Press.

Ghosh, A. 1992. In an antique land: history in the guise of a traveller's tale. New York: Vintage.

Gordon, R. 1995. Saving the last South African Bushman: a spectacular failing. Critical Arts 9(2): 28-48.

Gordon, R. 1999. Bain's Bushmen: scenes at the Empires Exhibition, 1936. In Africans on stage, ed. B. Lindfors, 266-289. Bloomington, Indiana: Indiana University Press.

Grant, J. 2011. Rural development in practice? The experience of the $\neq$ Khomani Bushmen in the Northern Cape, South Africa. Unpublished doctoral dissertation, University of Edinburgh.

Guignon, C.B. 2004. On being authentic. London: Routledge.

Handler, R. and W. Saxton. 1988. Dyssimulation: reflexivity, narrative, and the quest for authenticity in 'living history'. Cultural Anthropology 3(3): 242-260.

Hart, T.B. 2011. Community radio: the beat that develops the soul of the people? A case study of $\mathrm{XK}$ FM as an SABC-owned community radio station and its role as a 
facilitator of community-based development. Unpublished Master's dissertation, Centre for Communication, Media and Society, University of KwaZulu-Natal.

Heidegger, M. 1927. Being and time. Germany: SCM Books.

Huhn, T., ed. 2004. The Cambridge companion to Adorno. Cambridge: Cambridge University Press.

Humphreys, A.B. 1985. A kaleidoscope of values: changing perspectives on San society. Kronos 10(1): 58-66.

Husain, M.E. and K.J. Ayotte. 2005. Securing Afghan women: neocolonialism, epistemic violence, and the rhetoric of the veil. NWSA Journal 17(3): 112-133.

Isaacson, R. 2001. The healing land: a Kalahari journey. London: Fourth Estate. Isaacson, R. 2002. Last exit from the Kalahari: the slow genocide of the Bushmen/San. www.opendemocracy.net (accessed 25 January 2003).

Jay, M. 2006. Taking on the stigma of inauthenticity: Adorno's critique of genuineness. New German Critique 97: 15-30.

Jeursen, B. and K.G. Tomaselli. 2002. Romancing the Kalahari: personal journeys of methodological discovery. Current Writing: Text and Reception in Southern Africa 14(1): 29-58.

Kapoor, I. 2004. Hyper-reflexive development? Spivak on representing the Third-World 'Other'. Third World Quarterly 25(4): 627-647.

Kohn, E. 2007. How dogs dream: Amazonian natures and the politics of transpecies engagement. American Ethnologist 34(1): 3-24.

Lindfors, B., ed. 1999. Africans on stage: studies in ethnological show business. Bloomington, Indiana: Indiana University Press.

Lindholm, C. 2002. Authenticity, anthropology and the sacred. Anthropological Quarterly 75(2): 331-338.

Lyotard, J.F. 1991. The inhuman: reflections on time. Stanford: Stanford University Press.

Mahmood, M., ed. 2002. Beyond rights talk and culture talk. Cape Town: David Phillip.

Maingard, L.F. 1937. Introduction. In Bushman of the southern Kalahari, ed. J.D. Rheinallt Jones and C.M. Doke. Johannesburg: University of the Witwatersrand Press.

Marshall, L. 1976. The !Kung of Nyae-Nyae. Cambridge: Harvard University Press.

McCannel, D. 1973. Staged authenticity: arrangements of social space in tourist settings. The American Journal of Sociology 79(3): 589-603.

McLennan-Dodd, V. 2003. Hotel Kalahari: 'You can check out any time you like but you can never leave'. Cultural Studies <-> Critical Methodologies 3(4): 448-469.

McLennan-Dodd, V. 2004. 'The healing land': research methods in Kalahari communities. Critical Arts 18(2) (Literature and representation issue): 3-28.

Mhiripiri, N.A. 2012. A performative encounter with artist Silikat van Wyk in the Kalahari. Critical Arts 26(3): 375-400.

Mhlanga, B. 2006. Community radio as dialogic and participatory: a critical analysis of governance, control and community participation - a case study of XK FM radio. Unpublished Master's dissertation, Centre for Communication, Media and Society, University of KwaZulu-Natal.

Mufti, A.R. 2000. The aura of authenticity. Social Text 18(3): 86-103. 
Paddison, M. 2004. Authenticity and failure in Adorno's aesthetics of music. In The Cambridge companion to Adorno, ed. T. Huhn, 198-221. Cambridge: Cambridge University Press.

Peters, R. 2013. Anthro-tourism, documentary film and method. Journal of African Cinemas 5(1): 19-31.

Prins, F.E. 2009. Secret San of the Drakensberg and their rock art legacy. Critical Arts 23(2): 190-208.

Rabinow, P. 1986. Representations are social facts: modernity and post-modernity in anthropology. In Writing culture: the poetics and politics of ethnography, ed. J. Clifford and G.E. Marcus, 234-261. Berkeley: University of California Press.

Ramos, A.R. 1992. The hyperreal Indian. Série Antropologia no. 135, Universidade de Brasília, Instituto de Ciências Humanas, Departamento de Antropologia.

Rassool, C. and P. Hayes. 2002. Science and the spectacle: |Khanako's South Africa, 1936-37. In Deep histories, ed. W. Woodward, G. Minkley and P. Hayes, 117-161. Amsterdam: Rodopi.

Rheinallt, J.J.D. and C.M. Doke, eds. 1937. Bushmen of the southern Kalahari. Johannesburg: University of the Witwatersrand Press.

Robbins, D. 2006. A San journey: the story of the !Xun and Khwe of Platfontein. Sol Plaatje Educational Trust.

Robins, S. 1997. Transgressing the borderlands of tradition and modernity: identity, cultural hybridity and land struggles in Namaqualand (1980-94). Journal of Contemporary African Studies 15(1): 23-43.

Robins, S. 2000. Land struggles and the politics and ethics of representing 'Bushman' history and identity. Kronos 2000: 56-75.

Robins, S. 2001. NGOs, 'Bushmen' and double vision: the $\neq$ Khomani San land claim and the cultural politics of 'community' and 'development' in the Kalahari. Journal of Southern African Studies 27(4): 833-853.

Roy, A. 2002. God of small things. London: Penguin Books India.

Sharp, J. and S. Douglas. 1996. Prisoners of their reputation? The veterans of the 'Bushman Battalions' in South Africa. In Miscast, ed. P. Skotnes, 323-330. Cape Town: UCT Press.

Shiner, L. 1994. 'Primitive fakes', 'tourist art' and the ideology of authenticity. Journal of Aesthetics and Art Criticism 52(2): 225-234.

Simões, A. 2001. Issues of identity in relation to the Kalahari bushmen of southern Africa: a comparative analysis of two different bushmen groups during the late 1990 ond into 2001. Unpublished Master's dissertation, Centre for Communication, Media and Society, University of KwaZulu-Natal.

Skotnes, P., ed. 1996. Miscast: negotiating the presence of the Bushmen. Cape Town: UCT Press.

Smith, A.B. 1990. On becoming herders: Khoi-Khoi and San ethnicity in southern Africa. African Studies 49(2): 51-73.

Solway, J.S., R.B. Lee, A. Barnard, M.G. Bicchieri, A.C. Campbell, J. Denbow and R. Gordon et al. 1990. Foragers, genuine or spurious? Situating the Kalahari San in history [and comments and reply]. Current Anthropology 31(2): 109-146.

Spivak, G.C. 1990. Theory in the margin: Coetzee's Foe reading Defoe's Crusoe/Roxana. English in Africa 17(2): 1-23. 
Spivak, G.C. 1999. A critique of postcolonial reason: toward a history of the vanishing present. Cambridge, MA and London: Harvard University Press.

Steyn, H.P. 1984. Southern Kalahari subsistence ecology: a reconstruction. The South African Archaeological Bulletin 39: 117-124.

Suzman, J. 2001. An introduction to the regional assessment of the status of the San in southern Africa. Report no.1. Windhoek: Legal Assistance Centre.

Tobias, P.V. 1956. On the survival of the Bushmen. Africa 26(2): 174-186.

Tomaselli, K.G. 2001a. The semiotics of anthropological authenticity: the film apparatus and cultural accommodation. Visual Anthropology 14(2): 173-183.

Tomaselli, K.G. 2001b. Review essay: Rock art, the art of tracking and cybertracking: demystifying the 'Bushmen' in the age of information. Visual Anthropology 14: 7782.

Tomaselli, K.G. 2003. 'Dit is die Here se asem': the wind, its messages, and issues of autoethnographic methodology in the Kalahari. Cultural Studies $<->$ Critical Methodologies 3(4): 397-428.

Tomaselli, K.G. 2005. Where global contradictions are sharpest: research stories from the Kalahari. Vrije Universiteit, Amsterdam: Rozenberg.

Tomaselli, K.G. 2012. Cultural tourism and identity: rethinking indigeneity. Amsterdam: Brill.

Tomaselli, K.G. 2013. Visualizing different kinds of writing: autoethnography, social science. Visual Anthropology 26(1): 165-180.

Tomaselli, K., L. Dyll-Myklebust and S. van Grootheest. 2013. Personal/political interventions via autoethnography: dualisms, knowledge, power and performativity in research relations. In The handbook of autoethnography, ed. S. Holman Jones, T.E. Adams and C. Ellis. California: Left Coast Books.

Trilling, L. and L. Trilling. 2009. Sincerity and authenticity. Cambridge, MA and London: Harvard University Press.

Voss, A.E. 1990. 'Die Bushie is dood: Long live the Bushie' - black South African writers on the San. African Studies 49(1): 59-69.

Walker, C., T. Kepe and A. Bohlin, eds. 2010. Land, memory, reconstruction and justice. USA: Ohio University Press.

Wang, C. 2001. Is pro-poor tourism viable? Cultural tourism as sustainable development in Zulu and Bushman communities. Unpublished Master's dissertation, University of Natal, Durban. https://ccms.ukzn.ac.za/images/MA dissertations/caleb\%20wang\%20\%20ma\%2 odissertationpdf(accessed25January2014

Wessels, M. 2010. Bushman letters: interpreting /Xam narrative. Johannesburg: Wits University Press.

Wilmsen, E.N. and J. Denbow. 1990. Paradigmatic history of San-speaking people and current attempts at revision. Current Anthropology 31(5): 489-524.

Woodward, W., G. Minkley and P. Hayes, eds. 2002. Deep histories: gender and colonialism in southern Africa. Amsterdam: Rodopi.

Žižek, S. 1991. Grimaces of the real, or when the phallus appears. October 58(1): 45-68. 